\title{
Selected Quantitative Parameters Comparison of Apples from Bio- and Conventional Production
}

\author{
By Mezey Ján* \\ Serralegri Davide
}

\begin{abstract}
Aims of the research were to compare quantitative and qualitative parameters of apples from organic and conventional (integrated) production in following attributes: fruit weight, fruit diameter, juice yield, total sugar content, total acid content, fructose, glucose, malic acid, total soluble solids (TSS) and pH. A statistically significant difference between fruit diameter and fruit weight in organic and conventional system was observed, meanwhile in nutrition values just $p H$ showed difference $(p \leq 0.05)$ among all 11 varieties. According to measured parameters variety groups were created. The best variety for organic production was Kanzi, followed by Morgenduft, Red Delicious and Red Chief. For conventional production Fuji and Gala showed the highest performance followed by Braeburn, Golden Delicious and Pink Lady. Granny Smith and Envy can be used in both organic and conventional systems with medium performance.
\end{abstract}

Keywords: Apple, Conventional System, Nutritional Values, Organic Production.

\section{Introduction}

Fruit and vegetables have been recognized as important sources for a wide array of non-digestible components and phytochemicals that individually, or in combination, may act synergistically to contribute to the nutritional and health benefits of these food commodities. Recent research has shown that a wide range of indigenous fruit trees have the potential to provide rural households with a means to meet their nutritional and medicinal needs (Magaia et al., 2013). The demand for regional food locally produced is increasing, since these products are perceived as having better quality and taste, and are considered to be friendlier to the environment. There is also an increased interest from the consumer to know the producer behind the product. In addition, by consuming local foods the agriculture and the job market in the neighborhood can be supported (Jordbruksverket, 2010).

Apple (Malus domestica), belonging to the family Rosaceae, is one of the most nutritious and popular among all the fruits (Oboh, et al., 2012) and is one of the most important fruit crops in temperate regions. To date, many apple cultivars have been developed for various uses such as cooking, fresh eating, and cider production. HPLC assessment of sugar and organic acid composition has been conducted in several fruits such as berries (Mikulic-Petkovsek et al., 2012), stone fruits (Bae et al., 2014), and apple (Wu et al., 2007). Historically, apple has been one of the most important fruit and today apple trees extract 15 tons of carbonite

${ }^{*}$ Lecturer, Slovak Agriculture University in Nitra, Slovakia.

${ }^{\dagger}$ Slovak Agriculture University in Nitra, Slovakia. 
oxide and give 6 tons of oxygen in return (Garratt et al., 2016). Apples constitute an important part of the human diet, as they are a source of sugars, acids, and various biologically active compounds, such as phenolic compounds, which are responsible for most of the antioxidant activities of the fruit (Wu et al., 2007).

Epidemiological research has revealed an inverse correlation between apple consumption and many chronic human diseases (cardiovascular disease, asthma and pulmonary dysfunction, diabetes and cancer) (Boyer and Liu, 2004). There are few of the contents that are almost present in every fruit, such as water, sugars and vitamins. With these three contents as basic there is a difference in their ratios and few other components that constitute the nutrient makeup of any fruit. In case of apples following elements constitute together to make up the nutritional makeup of apple (Hyson, 2011).

Soluble sugars and organic acids are important components of fruit taste, and together with aromas, they have a strong impact on the overall organoleptic quality of fruits (Borsani et al., 2009). Malic, citric, and tartaric acids are not equally acidic. Therefore, fruit taste depends on the content and type of soluble sugars and organic acids (Bordonaba and Terry, 2010). The soluble sugar and organic acid composition has become a major focus of fruit tree breeding programs worldwide (Basha et al., 2012). The sugar and organic acid accumulation in apple fruits has two characteristics. One is that apple fruits are rich in fructose, which accounts for $44-75 \%$ of the total sugars (Wu et al., 2007). Another is that malic acid is the dominant acid in apple fruits, accounting for up to $90 \%$ of the total organic acids (Wu et al., 2007; Zhang et al., 2010).

Organic acid mostly increased during the early stages of fruit growth (30-60 days after full bloom) and decreased until fruits were fully ripened. Sucrose, fructose, and glucose content increased with fruit development (Bae, 2014). Malic acid occurs naturally in the fruits and is highly incorporated into the juices. The strong assencene and the flavor in the fruit, that stinginess in some acidic fruits are because of this acid (Nour, Trandafir and Ionica, 2010). Malic acid is the dominant acid in apple fruits, accounting for up to $90 \%$ of the total organic acids (Wu et al., 2007; Zhang et al., 2010) and has an important influence on the sour taste of apples. In cultivars with low amounts of malic acid, the sweet taste becomes predominant (Verberic et al., 2009); therefore, its content decreases during storage, particularly when high-oxygen content is present (Róth et al., 2007).

In fruits, soluble sugars are mainly composed of sucrose, fructose, and glucose, whilst malic, citric, and tartaric acids are the primary organic acids (Mahmood et al., 2012). The right proportion of these sugars attributes to the quality of the fruits (Wang et al., 2008). Fructose is one of the most abundant sugars in fruit juice (Wu et al., 2007). Some people believe fructose is healthier than sucrose because it is found naturally in fruit, however it can be equally harmful (Briffa, 2006).

Consumer awareness of the relationship between food and health, together with environmental concerns, has led to an increased demand for organically produced food. Consumer studies have shown multiple reasons for organic preferences, including environmental and socioeconomic concerns, taste preferences, and the belief that organic foods are healthier (Woese et al., 1997). 
The last decade has seen a significantly increased interest in organic food production, since conventional methods have caused various environmental problems (Boyer and Liu, 2004). Conventional (integrated) production is a concept of sustainable agriculture developed in 1976 which has gained international recognition and application. The concept is based on the use of natural resources and regulating mechanisms to replace potentially polluting inputs. The agronomic preventive measures and biological/physical/chemical methods are carefully selected and balanced taking into account the protection of health of both farmers and consumers and of the environment (IOBC, 2017). Cultivation type had an important influence on the polyphenolic level and antioxidant capacity of the apple fruits and leaves. Apples from organic production showed a higher content of hydroxycinnamic acids, flavanols, dihydrochalcones, quercetins and total phenolics than apples from integrated cultivation (MikulicPetkovsek, 2010).

Organic production is an ecological production management system that promotes and enhances biodiversity, biological cycles and soil biological activity. It is based on minimal use of off-farm inputs and on management practices that restore, maintain and enhance ecological harmony (IOBC, 2017).

There are limited numbers of studies comparing organically and conventionally grown fruit (or integrated practices with controlled fertilizer and pesticide use). These results are also difficult to compare, because of several methodological problems. The majority of these studies avoided assessing levels of secondary plant metabolites because their role in human health was not yet appreciated (Brandt and Mølgaard, 2001).

Aims of the work were to compare selected quantitative and qualitative parameters of apples from organic and conventional (integrated) production in following attributes: fruit weight, fruit diameter, juice yield, total sugar content, total acid content, fructose, glucose, malic acid, total soluble solids (TSS) and $\mathrm{pH}$ value.

\section{Materials and Methods}

Eleven apple varieties generated by FROM® Società Agricola Cooperativa, Terlano, Bolzano, Italy, and produced under organic and conventional production systems were assessed. Evaluated varieties were Braeburn, Envy, Fuji, Gala, Golden Delicious, Granny Smith, Kanzi, Morgenduft, Pink Lady, Red Delicious and Red Chief.

Fruit processing and analysis took place on 13 February 2017. For quantitative evaluation and nutritional value determination $10,000 \mathrm{~g}$ and $1000 \mathrm{~g}$, respectively were used. Fruits were cut after washing and put into a low-speed centrifugal juicer Magimix Le Duo Plus XL®; fruits were trimmed at $1200 \mathrm{rpm}$. Subsequently, the juice was filtered through a fine sieve and homogenized by mixing. The smear was plated into eight $15 \mathrm{ml}$ tubes, and centrifuged for 120 seconds and $6000 \mathrm{rpm}$. The centrifuged juice was separated through the filter paper and, using a syringe, the juice was injected into the spectrophotometer 
analyzer Bruker Optics, Alpha Wine Analyzer, juice module, FT-NIR UV/VIS. Values were exported to MS Office Excel and Stagraphics Centurion XVII program. The data was subjected to an analysis of variance and LSD $(p \leq 0.05)$ means comparison test. The juice yield was obtained by measuring of juice volume from $1000 \mathrm{~g}$ of fruit after juicing.

\section{Results and Discussion}

\section{Fruit Diameter}

Statistically significant difference between fruit diameter in organic and conventional system was observed (Table 1). Fruits from organic farming were $5.46 \%$ smaller and $16.23 \%$ lighter than those harvested from conventional production. Envy variety showed the larger negative difference in fruit diameter since fruits picked from conventional production were $13.78 \%$ smaller than those produced under organic farming. In the meantime Morgenduft variety observed the biggest positive difference since organic fruits were $2.93 \%$ bigger.

Table 1. Comparison of Apple Fruit Diameter Produced at Organic and Conventional Farming System

\begin{tabular}{|l|c|c|c|c|c|c|}
\hline \multirow{2}{*}{ variety } & \multicolumn{2}{|c|}{ bio } & \multicolumn{2}{c|}{ conventional } & \multicolumn{2}{c|}{ difference in \% } \\
\cline { 2 - 8 } & diam. & weight & diam. & weight & diam. & weight \\
\cline { 2 - 8 } & $(\mathbf{m m})$ & $(\mathbf{g})$ & $(\mathbf{m m})$ & $(\mathbf{g})$ & $(\mathbf{m m})$ & $(\mathbf{g})$ \\
\hline Braeburn & 70.74 & 188.89 & 74.32 & 213.64 & -4.81 & -11.58 \\
\hline Envy & 71.02 & 162.71 & 82.37 & 268.42 & -13.78 & -39.38 \\
\hline Fuji & 72.12 & 178.79 & 74.38 & 202.08 & -3.03 & -11.53 \\
\hline Gala & 69.34 & 160.66 & 75.65 & 208.70 & -8.34 & -23.02 \\
\hline Golden Delicious & 67.35 & 144.12 & 75.21 & 212.50 & -10.44 & -32.18 \\
\hline Granny Smith & 75.74 & 200.00 & 76.20 & 204.00 & -0.61 & -1.96 \\
\hline Kanzi & 68.57 & 155.56 & 72.75 & 182.35 & -5.74 & -14.70 \\
\hline Morgenduft & 76.67 & 168.33 & 74.48 & 175.86 & 2.93 & -4.28 \\
\hline Pink Lady & 74.21 & 192.98 & 73.20 & 188.00 & 1.38 & 2.65 \\
\hline Red Delicious & 69.83 & 165.52 & 76.14 & 213.64 & -8.29 & -22.52 \\
\hline Red Chief & 73.47 & 206.12 & 81.05 & 257.89 & -9.36 & -20.07 \\
\hline average & $\mathbf{7 1 . 7 3}$ & $\mathbf{1 7 4 . 8 8}$ & $\mathbf{7 5 . 9 8}$ & $\mathbf{2 1 1 . 5 5}$ & $\mathbf{- 5 . 4 6}$ & $\mathbf{- 1 6 . 2 3}$ \\
\hline
\end{tabular}

\section{Fruit Weight}

Statistically significant difference between fruit weight in organic and conventional system was observed (Table 1). The biggest negative difference in fruit weight was observed in Envy fruits from bio system, showing apples 39.38\% lighter than those from conventional production. Pink Lady variety recorded the biggest positive difference in fruit weight, then fruits from bio were $2.65 \%$ heavier 
than fruits from conventional production. Similar results were reported by Roussos and Gasparatos (2010).

\section{Juice Yield}

No statistically significant differences in juice yield was observed, however, Red Delicious yielded in organic system $70.73 \%$, which means 707.3 ml juice from $1000 \mathrm{~g}$ of fruits, and $22.99 \%$ higher than conventional system, where Fuji variety produced $74.38 \%$ of yield, which means $743.8 \mathrm{ml}$ juice from $1000 \mathrm{~g}$ of fruits (Table 2).

Table 2. Comparison of Juice Yield (\%) between Organic and Conventional Apple Production Systems

\begin{tabular}{|l|c|c|c|}
\hline Variety & Organic & Conventional & Difference \\
\hline & $\mathbf{( \% )}$ & $\mathbf{( \% )}$ & $\mathbf{( \% )}$ \\
\hline Braeburn & 69.60 & 65.81 & 5.75 \\
\hline Envy & 58.48 & 66.13 & -11.56 \\
\hline Fuji & 68.25 & 74.38 & -8.25 \\
\hline Gala & 65.89 & 66.17 & -0.43 \\
\hline Golden Delicious & 57.42 & 57.38 & 0.07 \\
\hline Granny Smith & 67.62 & 67.28 & 0.51 \\
\hline Kanzi & 68.57 & 66.29 & 3.44 \\
\hline Morgenduft & 57.08 & 54.25 & 5.23 \\
\hline Pink Lady & 65.72 & 69.09 & -4.88 \\
\hline Red Delicious & 70.73 & 57.51 & 22.99 \\
\hline Red Chief & 60.76 & 60.63 & 0.21 \\
\hline Average & 64.56 & 64.08 & 0.74 \\
\hline
\end{tabular}

\section{Nutritional Values}

In organic apple production system fructose and glucose represented $77.2 \%$ and $14.8 \%$, respectively from total sugar content, while malic acid produced $98.5 \%$ from total acid content (Table 3). Similar results were obtained by Wu et al. (2007), where fructose was the most dominant sugar in the different apple cultivars, followed by glucose and sucrose, while malic acid was the foremost organic acid.

Envy variety produced the highest fructose content $(114.17 \mathrm{~g} / \mathrm{l})$, and Granny Smith the lowest (79.08 g/l) content. The highest glucose content was obtained by Red Delicious ( $28.16 \mathrm{~g} / \mathrm{l})$, and the lowest by Envy ( $7.26 \mathrm{~g} / \mathrm{l})$, however, this variety showed the highest total soluble solids (14.45 Brix). Roussos and Gasparatos (2010) reported $12.66{ }^{\circ}$ Brix of organic apples were, while $12.4{ }^{\circ}$ Brix for conventional apples. The highest malic acid content $(9.58 \mathrm{~g} / \mathrm{l})$ and $\mathrm{pH}(3.46)$ were observed in Granny Smith and Envy varieties, respectively. Roussos and Gasparatos (2010) reported $\mathrm{pH}$ value of 4.11 in organic apples and 4.13 for conventional apples. The highest total acid content $(10.26 \mathrm{~g} / \mathrm{l})$ and sugar content 
(136.43 g/l) were produced by Granny Smith and Envy varieties, respectively. We confirmed also a study of Hecke et al. (2006), the acid content of both production types was similar.

Table 3. Nutritional Values in Organic Apple Production

\begin{tabular}{|l|c|c|c|c|c|c|c|}
\hline Organic & fructose & glucose & TSS & $\begin{array}{c}\text { malic } \\
\text { acid }\end{array}$ & $\mathbf{p H}$ & $\begin{array}{c}\text { total } \\
\text { acid }\end{array}$ & $\begin{array}{c}\text { total } \\
\text { sugar }\end{array}$ \\
\hline Braeburn & $(\mathrm{g} / \mathrm{l})$ & $(\mathrm{g} / \mathrm{l})$ & $\left({ }^{\circ} \mathrm{Brix}\right)$ & $(\mathrm{g} / \mathrm{l})$ & & $(\mathrm{g} / \mathrm{l})$ & $(\mathrm{g} / \mathrm{l})$ \\
\hline Envy & 114.17 & 12.69 & 12.29 & 6.20 & 3.29 & 6.37 & 109.27 \\
\hline Fuji & 88.46 & 23.79 & 13.45 & 4.63 & 3.46 & 5.24 & 136.43 \\
\hline Gala & 84.84 & 16.70 & 11.92 & 5.66 & 3.34 & 5.33 & 119.71 \\
\hline $\begin{array}{l}\text { Golden } \\
\text { Delicious }\end{array}$ & 98.51 & 8.97 & 12.65 & 5.05 & 3.33 & 4.99 & 109.05 \\
\hline Granny Smith & 79.08 & 25.34 & 13.00 & 9.58 & 3.20 & 10.26 & 120.60 \\
\hline Kanzi & 97.18 & 14.69 & 13.64 & 8.00 & 3.19 & 8.71 & 119.73 \\
\hline Morgenduft & 74.14 & 16.32 & 11.64 & 7.24 & 3.24 & 7.15 & 101.93 \\
\hline Pink Lady & 95.50 & 8.25 & 12.82 & 6.88 & 3.28 & 7.44 & 119.20 \\
\hline $\begin{array}{l}\text { Red } \\
\text { Delicious }\end{array}$ & 84.61 & 28.16 & 13.39 & 5.40 & 3.36 & 5.07 & 120.49 \\
\hline Red Chief & 81.45 & 27.88 & 13.50 & 5.70 & 3.33 & 5.38 & 120.05 \\
\hline $\begin{array}{l}\text { Average } \\
\text { value }\end{array}$ & 89.91 & 17.28 & 12.99 & 6.37 & 3.31 & 6.47 & 116.48 \\
\hline Standard dev. & 11.14 & 7.86 & 0.83 & 1.45 & 0.08 & 1.74 & 9.62 \\
\hline
\end{tabular}

In conventional apple production system fructose and glucose represented $77.0 \%$ and $17.5 \%$, respectively from total sugar content, while $98.5 \%$ of total acid is malic acid (Table 4), results confirmed by Wu et al. (2007) and Zhang et al. (2010).

The highest fructose content (102.76 g/l) was reported on Envy variety, which means $40 \%$ higher than those values obtained by Róth et al. (2007) in organic apples $(61.2 \mathrm{~g} / \mathrm{l})$ and in conventional system $(62.3 \mathrm{~g} / \mathrm{l})$. Red Chief variety produces the highest glucose content $(32.91 \mathrm{~g} / \mathrm{l})$, similar to those values reported by Róth et al. (2007) in organic apples $(12.55 \mathrm{~g} / \mathrm{l})$ and in conventional system (13.3 g/l). Fuji cultivar has the highest TSS content $\left(14.41^{\circ} \mathrm{Brix}\right)$ and total sugar content (126.27 g/l), results similar to Hecke et al. (2006), while Granny Smith showed the maximum malic acid $(9.82 \mathrm{~g} / \mathrm{l})$ as well as the highest total acid $(10.34 \mathrm{~g} / \mathrm{l})$. The highest $\mathrm{pH}$ level was by variety Envy 3.31 . 
Table 4. Nutritional Values in Conventional Apple Production

\begin{tabular}{|l|c|c|c|c|c|c|c|}
\hline CONVENTIONAL & fructose & glucose & TSS & $\begin{array}{c}\text { malic } \\
\text { acid }\end{array}$ & pH & $\begin{array}{c}\text { total } \\
\text { acid }\end{array}$ & $\begin{array}{c}\text { total } \\
\text { sugar }\end{array}$ \\
\hline & $(\mathrm{g} / \mathrm{l})$ & $(\mathrm{g} / \mathrm{l})$ & $\left({ }^{\circ} \mathrm{Brix}\right)$ & $(\mathrm{g} / \mathrm{l})$ & & $(\mathrm{g} / \mathrm{l})$ & $(\mathrm{g} / \mathrm{l})$ \\
\hline Braeburn & 86.95 & 17.58 & 12.42 & 7.28 & 3.16 & 7.78 & 112.62 \\
\hline Envy & 102.76 & 10.62 & 13.16 & 5.29 & 3.31 & 5.45 & 121.78 \\
\hline Fuji & 91.41 & 29.17 & 14.41 & 6.79 & 3.21 & 6.61 & 126.27 \\
\hline Gala & 86.99 & 18.43 & 12.83 & 6.97 & 3.24 & 6.84 & 112.05 \\
\hline Golden Delicious & 92.82 & 18.25 & 13.23 & 6.24 & 3.19 & 6.31 & 115.63 \\
\hline Granny Smith & 78.92 & 25.63 & 11.70 & 9.82 & 3.12 & 10.34 & 108.47 \\
\hline Kanzi & 92.74 & 17.53 & 13.21 & 7.61 & 3.20 & 7.83 & 115.52 \\
\hline Morgenduft & 80.06 & 12.13 & 11.15 & 6.12 & 3.16 & 6.16 & 97.32 \\
\hline Pink Lady & 96.97 & 10.52 & 12.92 & 7.28 & 3.13 & 8.17 & 118.64 \\
\hline Red Delicious & 78.04 & 26.97 & 11.97 & 5.42 & 3.28 & 4.89 & 110.29 \\
\hline Red Chief & 78.10 & 32.91 & 12.57 & 5.08 & 3.26 & 4.64 & 116.35 \\
\hline Average value & 87.80 & 19.98 & 12.69 & 6.72 & 3.21 & 6.82 & 114.09 \\
\hline Standard dev. & 8.37 & 7.67 & 0.88 & 1.35 & 0.06 & 1.65 & 7.56 \\
\hline
\end{tabular}

Conventional farming produced apples with statistically higher fruit weight, fruit diameter and $\mathrm{pH}$ than those obtained from organic system (Figure 1); then the fruit quality according to the other parameters is similar among the eleven varieties.

Similar result are reported by Lombardi-Boccia et al. (2004), Peck et al. (2006), Róth et al. (2007) and Roussos and Gasparatos (2010), since they also found not significant difference in nutritional values (TSS, pH, malic acid, and total acids) of apples produced under organic and conventional farms.

Figure 1. Means Comparisons of Nutritional Values Evaluated in 11 Apple Varieties Harvested from Organic and Conventional Production Systems

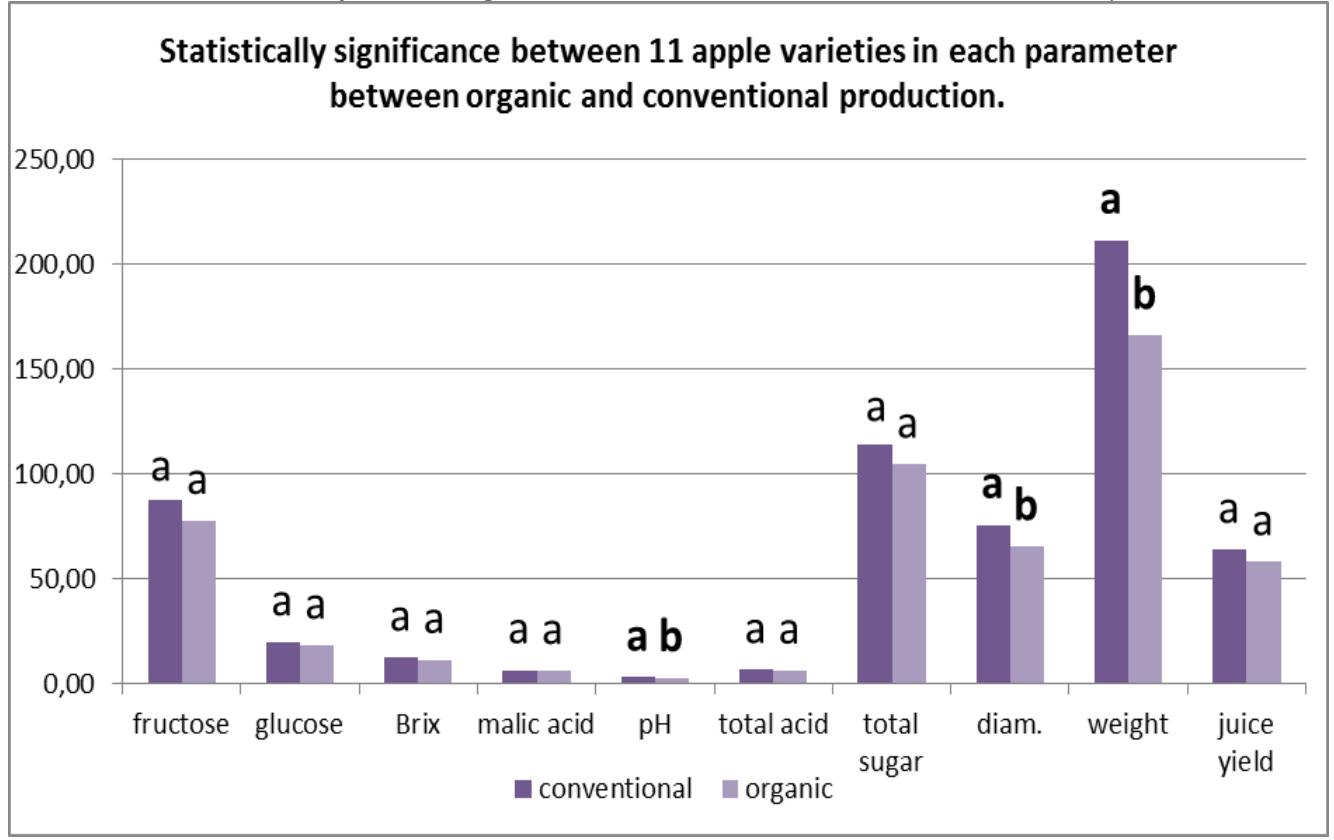

Means with the same letter in the frame are statistically equals (LSD, $p<0.05$ ). 


\section{Differences in Nutritional Values between Conventional and Organic Apples}

The highest negative difference in fructose content was observed in Morgenduft variety $(-7.39 \%)$, which means that organic farming produced apples with $7.39 \%$ of fructose content, a lower value than those harvested from conventional system; however, the same variety showed the highest positive differences for glucose, malic acid, and total acid, as well as good values of TSS and total sugar (Table 5). Similar performance showed Kanzi, Red Delicious and Red Chief varieties (Table 6), and then all of them represent an excellent alternative to produce a good quality apple under bio system farming.

Even though Envy variety showed the highest positive difference in fructose $(11.1 \%)$ and total sugar content $(12.03 \%)$, it has a medium value of glucose, malic acid, $\mathrm{pH}$, and total acid. As a result this tree can be used in both organic and conventional systems, as well as Granny Smith cultivar. Finally, Fuji, Gala, Braeburn, Golden Delicious, and Pink Lady, are probably varieties developed for conventional systems, since they showed the highest negative difference in glucose (Golden Delicious), pH (Pink Lady), and total sugar content (Gala).

As reported by Mikulic-Petkovsek (2010), the impact of the organic type of apple production is reflected in the content of total phenols. In 2009, on all sampling dates, the leaves from organic production had 10-20\% higher levels of total phenols than those from integrated production. In 2008, the ranking of the content of total phenols in leaves was almost the same in both types of production

Table 5. Differences in Nutritional Values (\%) between Conventional and Organic Apple Production

\begin{tabular}{|l|c|c|c|c|c|c|c|}
\hline $\begin{array}{l}\text { Difference } \\
\text { conventional/ } \\
\text { organic }\end{array}$ & fructose & glucose & $\mathbf{T S S}$ & $\begin{array}{c}\text { malic } \\
\text { acid }\end{array}$ & $\mathbf{p H}$ & $\begin{array}{c}\text { total } \\
\text { acid }\end{array}$ & $\begin{array}{c}\text { total } \\
\text { sugar }\end{array}$ \\
\hline & $\mathbf{( \% )}$ & $\mathbf{( \% )}$ & $\mathbf{( \% )}$ & $\mathbf{( \% )}$ & $\mathbf{( \% )}$ & $\mathbf{( \% )}$ & $\mathbf{( \% )}$ \\
\hline Braeburn & 4.74 & -27.82 & -1.05 & -14.84 & 4.11 & -18.12 & -2.97 \\
\hline Envy & 11.10 & -31.64 & 9.80 & -12.48 & 4.53 & -3.85 & 12.03 \\
\hline Fuji & -3.23 & -18.44 & -5.55 & -16.64 & 4.05 & -19.36 & -5.20 \\
\hline Gala & -2.47 & -9.39 & -7.09 & -17.93 & 4.01 & -22.81 & -6.42 \\
\hline Golden Delicious & 6.13 & -50.85 & -4.38 & -19.07 & 4.39 & -20.92 & -5.69 \\
\hline Granny Smith & 0.20 & -1.13 & 11.11 & -2.44 & 2.56 & -0.77 & 11.18 \\
\hline Kanzi & 4.79 & -16.20 & 3.26 & 5.12 & -0.31 & 11.24 & 3.64 \\
\hline Morgenduft & -7.39 & 34.54 & 4.39 & 18.30 & 2.53 & 16.07 & 4.74 \\
\hline Pink Lady & -1.52 & -21.58 & -0.77 & -5.49 & 4.79 & -8.94 & 0.47 \\
\hline Red Delicious & 8.42 & 4.41 & 11.86 & -0.37 & 2.44 & 3.68 & 9.25 \\
\hline Red Chief & 4.29 & -15.28 & 7.40 & 12.20 & 2.15 & 15.95 & 3.18 \\
\hline Average & 2.40 & -13.51 & 2.36 & -5.21 & 3.12 & -5.13 & 2.09 \\
\hline
\end{tabular}


Table 6. Suitability of Tested Apple Varieties for Organic or Conventional Production Systems according to Overall Nutrition Values

\begin{tabular}{|c|c|c|c|c|c|c|c|c|c|}
\hline $\begin{array}{l}\text { Suitability } \\
\text { organic/ } \\
\text { conventional }\end{array}$ & fruct. & gluc. & TSS & $\begin{array}{l}\text { malic } \\
\text { acid }\end{array}$ & pH & $\begin{array}{l}\text { total } \\
\text { acid }\end{array}$ & $\begin{array}{l}\text { total } \\
\text { sugar }\end{array}$ & org. & conv. \\
\hline Braeburn & & & & & & & & 1 & 6 \\
\hline Envy & & & & & & & & 3 & 4 \\
\hline Fuji & & & & & & & & 0 & 7 \\
\hline Gala & & & & & & & & 0 & 7 \\
\hline $\begin{array}{l}\text { Golden } \\
\text { Delicious }\end{array}$ & & & & & & & & 1 & 6 \\
\hline $\begin{array}{l}\text { Granny } \\
\text { Smith }\end{array}$ & & & & & & & & 3 & 4 \\
\hline Kanzi & & & & & & & & 6 & 1 \\
\hline Morgenduft & & & & & & & & 5 & 2 \\
\hline Pink Lady & & & & & & & & 1 & 6 \\
\hline $\begin{array}{l}\text { Red } \\
\text { Delicious }\end{array}$ & & & & & & & & 5 & 2 \\
\hline Red Chief & & & & & & & & 5 & 2 \\
\hline Average & & & & & & & & 3 & 4 \\
\hline
\end{tabular}

\section{Conclusions}

Fruits from organic farming were $5.46 \%$ smaller and $16.23 \%$ lighter than fruits from conventional production. No significantly differences were found for juice yield; however, Red Delicious and Fuji varieties produced the highest yield in organic (70.73\%) and conventional farming (74.38\%), respectively. According to the six measured parameters the best variety for organic production was Kanzi, and for conventional production were Fuji and Gala.

\section{References}

Bae, H., Yun, S. K., Jun, J. H., Yoon, I. K., Nam, E. Y. and Kwon, J. H. 2014. Assessment of organic acid and sugar composition in apricot, plumcot, plum, and peach during fruit development. Journal of Applied Botany and Food Quality, 87: 24-29. 
Basha, S. M., Vasanthaiah, H. K., Kambiranda, D. M., Easwaran, K. and Queeley, G. 2012. Genetic variation in sugar composition among muscadine, Florida hybrid bunch and bunch grape genotypes. International Journal of Wine Research, 4: 15-23.

Bordonaba, J. G. and Terry, L. A. 2010. Manipulating the taste-related composition of strawberry fruits (Fragaria ananassa) from different cultivars using deficit irrigation. Food Chemistry, 122(4): 1020-1026.

Borsani, J., Budde, C. O., Porrini, L., Lauxmann, M. A., Lombardo, V. A., Murray, R. 2009. Carbon metabolism of peach fruit after harvest: Changes in enzymes involved in organic acid and sugar level modifications. Journal of Experimental Botany, 60(6): 1823-1837.

Boyer, J. and Liu, R H. 2004. Apple phytochemicals and their health benefits. Nutr J 3:5.

Brandt, K and Mølgaard J. P. 2001. Organic agriculture: does it enhance or reduce the nutritional value of plant foods? J Sci Food Agric 81:924-931.

Briffa J. 2006. Juicy Details-Why Fruit Juices Pose a Hazard to Our Health. http://www. drbriffa.com/2006/11/10/juicy-details-why-fruit-juices-pose-a-hazard-to-our-health/.

DeEll, J. R. and Prange, R. K. 1992. Postharvest quality and sensory attributes of organically and conventionally grown apples. HortScience, 27(10): 1096-1099.

Garratt M. P. D., Breeze T. D., Boreux V., Fountain M. T., McKerchar M., Webber S. M. 2016. Apple Pollination: Demand Depends on Variety and Supply Depends on Pollinator Identity. PLoS ONE 11(5): e0153889. https://doi.org/10.1371/journal.po ne.0153889.

Hecke, K., Herbinger, K., Veberic, R., Trobec, M., Toplak, H., Stampar, F., Keppel, H., Grill, D. 2006. Sugar-, acid- and phenol contents in apple cultivars from organic and integrated fruit cultivation. Eur J Clin Nutr. 60(9):1136-40.

Hyson D. 2011. A Comprehensive Review of Apples and Apple Components and Their Relationship to Human Health. Advances in Nutrition 2:408-420.

Jordbruksverket, 2010. Rapport 2010:19. Hållbar konsumtion av jordbruksvaror - vad får $\mathrm{du}$ som konsument när du köper närproducerat? [Sustainable Consumption of Agricultural Products -What do you get as a consumer when you buy after-sales?] [Online]. Available from: http://www2.jordbruks verket.se/webdav/files/SJV/tryck saker/Pdf_rapporter/ra10_19.pdf [2010-12-06].

Koư̌imská, L., Kubaschová, K., Sus, J., Nový, P., Dvořáková, B. and Koudela, M. 2014. Comparison of the carbohydrate content in apples and carrots grown in organic and integrated farming systems. Potravinarstvo Slovak Journal of Food Sciences, 8(1), 178-183.

Lombardi-Boccia, G., Lucarini, M., Lanzi, S., Aguzzi, A. and Cappelloni, M. 2004. Nutrients and antioxidant molecules in yellow plums (Prunus domestica L.) from conventional and organic productions: a comparative study. J. Agric. Food Chem., 52:90-94.

Magaia, T., Uamusse., A., Sjöholm., I. and Skog., K. 2013. Dietary fiber, organic acids and minerals in selected wild edible fruits of Mozambique. Springer Plus 2, 88.

Mahmood T., Anwar F., Abbas M., Boyce M. C., Saari N. 2012. Compositional variation in sugars and organic acids at different maturity stages in selected small fruits from Pakistan. International Journal of Molecular Sciences, 13:1380-1392.

Mikulic Petkovsek M., Slatnar A., Stampar F., Veberic R. 2010. The influence of organic/ integrated production on the content of phenolic compounds in apple leaves and fruits in four different varieties over a 2-year period. J Sci Food Agric. 2010 Nov; 90(14):2366-78. Doi: 10.1002/jsfa.4093.

Mikulic-Petkovsek, M., Schmitzer, V., Slatnar, A., Stampar, F. and Veberic, R. 2012. Composition of sugars, organic acids, and total phenolics in 25 wild or cultivated berry species. Journal of Food Science, 77(10), C1064 C1070. 
Nour, V., Trandafir, I. and Ionica, M. 2010. Compositional Characteristics of Fruits of several Apple (Malus domestica Borkh.) Cultivars. Notulae Botanicae Horti Agrobotanici Cluj-Napoca, 38(3):12-17.

Oboh G., Ademosun A. O. 2012. Characterization of the antioxidant properties of phenolic extracts from some citrus peels. J. Food Sci. Technol., 49:729-736.

Peck, G. M., Andrews, P. K., Reganold, J. P. and Fellman, J. K. 2006. Apple orchard productivity and fruit quality under organic, conventional and integrated management. Hortscience, 41: 99-107.

Róth, E., Berna, A., Beullens, K., Yarramraju, S., Lammertyn, J., Schenk, A. and Nicolai, B. 2007. Postharvest quality of integrated and organically produced apple fruit. Postharvest Biology and Technology, 45(1), 11-19.

Roussos, P. A. and Gasparatos, D. 2010. Apple tree growth and overall fruit quality under organic and conventional orchard management. Sci. Hortic. 2010, 123, 247-252.

Wang, S. I., Chen, Ch., Sciarappa, W., Wang, Ch. and Camp, M. J. 2008. Fruit Quality, Antioxidant Capacity, and Flavonoid Content of Organically and Conventionally Grown Blueberries. J. Agric. Food Chem., 56(14):5788-94. Doi: 10.1021/jf703775r.

Woese, K., Lange, D., Boess, C. and Bogl, K. W. 1997. A comparison of organically and conventionally grown foods: results of a review of the relevant literature. J Sci Food Agric 74:281-293.

Wu, J., Gao, H., Zhao, L., Liao, X., Chen, F., Wang, Z., Hu, X. 2007. Chemical compositional characterization of some apple cultivars. Food Chemistry, 103, 88-93.

Zhang, Y., Li, P., Cheng, L. 2010. Developmental changes of carbohydrates, organic acids, amino acids, and phenolic compounds in 'Honeycrisp' apple flesh. Food Chemistry, 123 (4):1013-1018. 
